\title{
Are You Ready to Use Technology in EFL Teaching? Examining Psychometric Properties of EFL Teachers' Technological Pedagogical Content Knowledge (TPACK) Scale
}

\author{
Liwei Hsu (Corresponding author) \\ Professor, National Kaohsiung University of Hospitality and Tourism \\ No. 1, Sunghe Rd., Hsiao-Kang District, Kaohsiung City, Taiwan \\ Tel: 886-78060505 E-mail: liweihsu@mail.nkuht.edu.tw
}

Received: December 17, 2015 Accepted: January 10, 2016 Published: March 5, 2016

doi:10.5296/ire.v4i1.8740 URL: http://dx.doi.org/10.5296/ire.v4i1.8740

\begin{abstract}
It has been confirmed that technology can be beneficial for students' academic performance, including in the field of computer-assisted language learning (CALL). The successful administration of CALL depends greatly on the teachers' knowledge about technology, pedagogy and content. The aim of this study is to explore the psychometric property of measure of EFL teachers' technological, Pedagogical and content knowledge (TPACK). One hundred and fifty-eight EFL teachers were invited to join this study through stratified randomization sampling technique. The research instrument was the TPACK-EFL and the exploratory factor analysis (EFA) with extraction method of Maximum Likelihood and the rotation method of Promax with Kaiser Normalization, was performed to extracted factors with factor loading above .50. Seven constructs (Technological Knowledge, Pedagogical Knowledge, Content Knowledge, Technological Pedagogical Knowledge, Technological Content Knowledge, Pedagogical Content Knowledge and Technological Pedagogical Content Knowledge) were retrieved. Afterwards, the Confirmatory Factor Analysis (CFA) was undertaken to examine the convergent and discriminant validity of selected factors. Convergent validity was checked with Composite Reliability (CR), Average Variance Extracted (AVE), Maximum Shared Variance (MSV), and Average Shared Variance (ASV). Suggested value for CR and AVE was .6 and .5 respectively while MSIV as well as ASV should be lower than AVE. Results showed that constructs of this study all met the
\end{abstract}


requirement which indicated that the items had convergent validity. In terms of discriminant validity, square root of AVE was greater than inter-construct correlations which asserted the discriminant validity of this instrument. Subsequently, alternate model analysis was conducted to yield the model which fitted the best as indicated by the model fit indices and research context.

Keywords: Technology, Pedagogy, Content Knowledge (TPACK), English as a Foreign Language (EFL) Teaching, Computer Assisted Language Learning (CALL)

\section{Introduction}

Given the fact that many of students of nowadays are considered as "Net Generation" (D. Oblinger, 2003) or/and "digital natives" (Prensky, 2001); technology has taken up many aspects of their daily lives as well as the way to think and learn (D. G. Oblinger, 2010). It has been a rigorous debate about whether the application of technology will be able to enhance students' learning (Hew \& Cheung, 2014) and more and more empirical evidence have shown that technology is indeed beneficial for students' academic performance (Hsu, Hwang, \& Chang, 2013; Tamim, Bernard, Borokhovski, Abrami, \& Schmid, 2011). It has been argued that in this digital age, utilising pedagogically and technologically sound means of pedagogy is able to respond the expectation of stakeholders (Roth, 2015) and teachers are advised to use technology effectively in and out of classroom (Bunch, Robinson, \& Edwards, 2015); nevertheless, caution has been advised that the focus of technology-integrated pedagogy should not be the technology per se but about how it is being planned based on the affordances and functionalities (Schmid et al., 2014; Wurst, Smarkola, \& Gaffney, 2008). Furthermore, technology should not be taken as a medium for material delivery; rather, it should be utilized as a means of cognitive support (Tamim, Borokhovski, Pickup, Bernard, \& El Saadi, 2015). The lack of a teacher's knowledge of how to use technology effectively and meaningfully in instruction is identified as a major barrier to such uses (Kabakci Yurdakul et al., 2012). Therefore, gravity has been given to the issue of how to effectively integrate technology in education to optimize students' learning effectiveness is gaining momentum (Deutsch, 2010).

When technologies are applied in EFL teaching and learning, the typology of computer-assisted language learning (CALL) has been created. CALL embraces a wide range of applications of information communication technologies (ICTs) in language teaching (Levy, 1997) and language learners' learning with, or through and around computers (Egbert, 2005). Along with the expeditious development of ICTs, language teachers around the world started to consider computer as an important essence of language pedagogy (Dina \& Ciornei, 2013). Taking modern concept of modern language education, the focus of language education program should be on the learners' communicative competence (Martin, 2015) and therefore Previous studies have asserted that CALL may be beneficial for language learners' attainment (Nachoua, 2012). Because of such encouraging results, in reality, quite a lot of practitioners as well as policy makers are aware of the advantage of technology in teaching and learning and thus make investments on the technical infrastructure. However, little attention has been paid to the consideration from pedagogical perspective (Tamim et al., 2015) 
which infuse the meaningfulness in CALL. Moreover, the effectiveness of CALL depends significantly on teachers' knowledge in technology, pedagogy as well as contents of the subject matters (which is the target language in the context of CALL) (Wu, 2015). Language teachers' technological pedagogical content knowledge (TPACK) is an intriguing topic to be addressed when technology is adopted as a part of curriculum design because TPACK suggests that teachers as well as curriculum designers understand how knowledge about technology, pedagogy and content interact with each other in the process of instruction (Rosenberg \& Koehler, 2015)

The theoretical framework of TPACK is derived from the conceptual work of Shulman (1986) who developed PCK as the pedagogical and content knowledge for educators. Mishra and Koehler (2006) acknowledged the important role that technology will be playing in innovative pedagogy and hence added technology as an essential part to PCK and came up with TPACK which aimed to explore the interweaving relationships among technology, pedagogical and content knowledge equipped by a teacher as a "Total PACKage" (Thompson \& Mishra, 2007). TPACK has been applied as a conceptual framework in the areas of research in mathematics, social science, science and English; even so, it is still in logical analysis rather than empirical evidence (Kelly, 2010). He further suggested that the definition of TPACK should be explicitly identified and reliable, valid and usable method of measurement should be developed and demonstrated.

Concerning the TPACK researched in the field of EFL teaching with the help of CALL, it is still in the infancy phase which still calls for academic attention to provide empirical evidence (Debbagh \& Jones, 2015; Wu, 2015). The gravity of preparing EFL pre-service teachers with competent TPACK has been acknowledged (Koçoğlu, 2009; Kurt, Mishra, \& Kocoglu, 2013) and therefore, a reliable and valid instrument is expected to be developed. To respond this call, Baser, Kopcha, and Ozden (2015) developed a research instrument to specifically measure EFL teachers' TPACK; however, it was undertaken within western context and its applicability in other cultural contexts remains un-explored. The present research aims to examine the psychometric property of measuring EFL teachers' TPACK in Taiwan through a serial model comparisons.

\section{Research Design and Methodology}

There were 200 EFL teachers at secondary level in Taiwan being invited through stratified random sampling to join this survey and a total number of 158 of them $(n=158)$ responded to this request and finished the survey. Participants' demographic information is presented in the following Table 1. 
Table 1. Participants' Demographic Data

\begin{tabular}{cccc}
\hline Variable & Category & $\mathrm{n}$ & $\%$ \\
\hline Gender & Male & 52 & $32.91 \%$ \\
& Female & 106 & $67.09 \%$ \\
Years of Teaching & less than 3 years & 63 & $39.88 \%$ \\
& $4-6$ years & 51 & $32.28 \%$ \\
& $7-9$ years & 41 & $25.95 \%$ \\
Location of Schools & More than 10 years & 3 & $0.02 \%$ \\
& Northern & 53 & $33.54 \%$ \\
& Central & 42 & $26.58 \%$ \\
& Southern & 63 & $39.87 \%$ \\
\hline
\end{tabular}

Information presented in Table 1 showcased that females EFL teachers were about twice of the number of their male counterparts. As for their teaching experience, more than $70 \%$ of them had been EFL teachers less than 6 years. The geographic data about the location of schools which selected by this present study also reflects the big picture of current situation in Taiwan and thus it is sound to state that results elicited from this study had certain level of generalizability.

The research instrument was the questionnaire developed by Baser, Kopcha and Ozden (2015) which was translated into Chinese for better comprehension to the participants. To ensure the accuracy and quality of translation, the Chinese version was back-translated into English and was reviewed by two native-speaker of English who were on the faculty of a national university in Taiwan. All the items were responded with Likert 5-point scale $(1=$ strongly disagree and $5=$ strongly agree). After the surveys were collected, statistical analyses were in process to measure the psychometric property of it.

\section{Results}

Firstly, Exploratory Factor Analysis (EFA) was undertaken to clean the data and only items with sufficient factor loading would be selected. Results of KMO and Bartlett's Test of Sphericity confirmed the adequacy of EFA $(\mathrm{KMO}=.88, \mathrm{p}=.00)$. With extraction method of Maximum Likelihood and the rotation method of Promax with Kaiser Normalization. Seven factors were elicited with factor loading above .50 thresholds. In the end, there were 6 items for the construct of Technology Knowledge (TK) and 5 items were retained to measure EFL teachers' Pedagogy Knowledge (PK) and Content Knowledge (CK). In terms of integrated knowledge, 5 items were found to have sufficient factor loading for the construct of Pedagogy Content Knowledge (PCK) and 3 items were adopted to examine Technology Content Knowledge (TCK). Only two items were extracted in the construct of Technology Pedagogy Knowledge (TPK). For the Technology Pedagogy Content Knowledge (TPACK) construct, most of items were ruled out and only 1 item was kept. Details of factor loadings of the seven extracted factors are presented in the following Table 2. 


\section{Macrothink}

Table 2. Factor Loadings of Each Selected Item

\begin{tabular}{|c|c|c|c|c|c|c|c|}
\hline & 1 & 2 & 3 & 4 & 5 & 6 & 7 \\
\hline CK1 & .953 & & & & & & \\
\hline CK2 & .827 & & & & & & \\
\hline CK3 & .674 & & & & & & \\
\hline CK4 & .616 & & & & & & \\
\hline CK6 & .600 & & & & & & \\
\hline CK5 & .578 & & & & & & \\
\hline PK5 & & .882 & & & & & \\
\hline PK4 & & .879 & & & & & \\
\hline PK1 & & .850 & & & & & \\
\hline PK3 & & .793 & & & & & \\
\hline PK2 & & .783 & & & & & \\
\hline PCK1 & & & .867 & & & & \\
\hline PCK3 & & & .801 & & & & \\
\hline PCK2 & & & .795 & & & & \\
\hline PCK4 & & & .685 & & & & \\
\hline PCK5 & & & .531 & & & & \\
\hline TK2 & & & & .862 & & & \\
\hline TK3 & & & & .778 & & & \\
\hline TK1 & & & & .671 & & & \\
\hline TK4 & & & & .639 & & & \\
\hline TK5 & & & & .617 & & & \\
\hline \multicolumn{8}{|l|}{ TK6 } \\
\hline TCK2 & & & & & .799 & & \\
\hline TCK3 & & & & & .665 & & \\
\hline TCK1 & & & & & .548 & & \\
\hline TPK2 & & & & & & .732 & \\
\hline TPK1 & & & & & & .708 & \\
\hline TPACK1 & & & & & & & .505 \\
\hline
\end{tabular}

Note: Extraction Method: Maximum Likelihood.

Rotation Method: Promax with Kaiser Normalization.

Reliability of these selected factors was measured with Cronbach's $\alpha$ and the results of these seven constructs were $\mathrm{TK}=.91, \mathrm{CK}=.88, \mathrm{PK}=.92, \mathrm{PCK}=.88, \mathrm{TCK}=.75$ and $\mathrm{TPK}=.75$. All of them were above the threshold value of .70 as suggested by Geourge and Mallery (2003); therefore, it is sound to say that the question items was reliable. After the reliability was examined and confirmed, Confirmatory Factor Analysis (CFA) was undertaken to examine the convergent and discriminant validity of selected factors. Convergent validity was checked with Composite Reliability (CR), Average Variance Extracted (AVE), Maximum Shared Variance (MSV), and Average Shared Variance (ASV). The thresholds for these values to have adequate convergent validity are that $C R$ should be greater than .70 while AVE 


\section{Macrothink}

should be greater than .50 . The discriminant validity can be ensured when AVE of each construct is greater than NSV and ASV; moreover, the square root of AVE should be greater than inter-construct correlations and the results of such analyses showed that this survey had good construct validity. Details about the construct validity (both discriminant and convergent validity) analysis are presented in the Table 3 below.

Table 3. Construct Validity Analysis of Constructs

\begin{tabular}{lllllllllll}
\hline & CR & AVE & MSV & ASV & TCK & TK & CK & PK & PCK & TPK \\
\hline TCK & .76 & .51 & .33 & .18 & .71 & & & & & \\
TK & .91 & .63 & .51 & .26 & .36 & .80 & & & & \\
CK & .88 & .55 & .51 & .17 & .29 & .71 & .74 & & & \\
PK & .92 & .70 & .10 & .04 & .32 & .12 & .19 & .84 & & \\
PCK & .88 & .59 & .50 & .23 & .51 & .70 & .38 & .18 & .77 & \\
TPK & .76 & .61 & .33 & .16 & .57 & .39 & .27 & .17 & .44 & .78 \\
\hline
\end{tabular}

Afterwards, alternate model analysis was undertaken to yield a model to be the representative of model specifications which can be used in practice (Flora \& Curran, 2004). Other than the null model, this present study proposed 4 alternate models. Model 1 was the $1^{\text {st }}$ Order 6 factors with no correlation between factors and Model 2 was the $1^{\text {st }}$ order single factor, which was TPACK, measuring all items. Model 3 represented $1^{\text {st }}$ Order 6 factors with correlation between factors and the last model was the $2^{\text {nd }}$ order 6 factors Model. Details are presented in the following figures (Figure 1 Figure 4 ) and model fit indices of these models are depicted in Table 3.

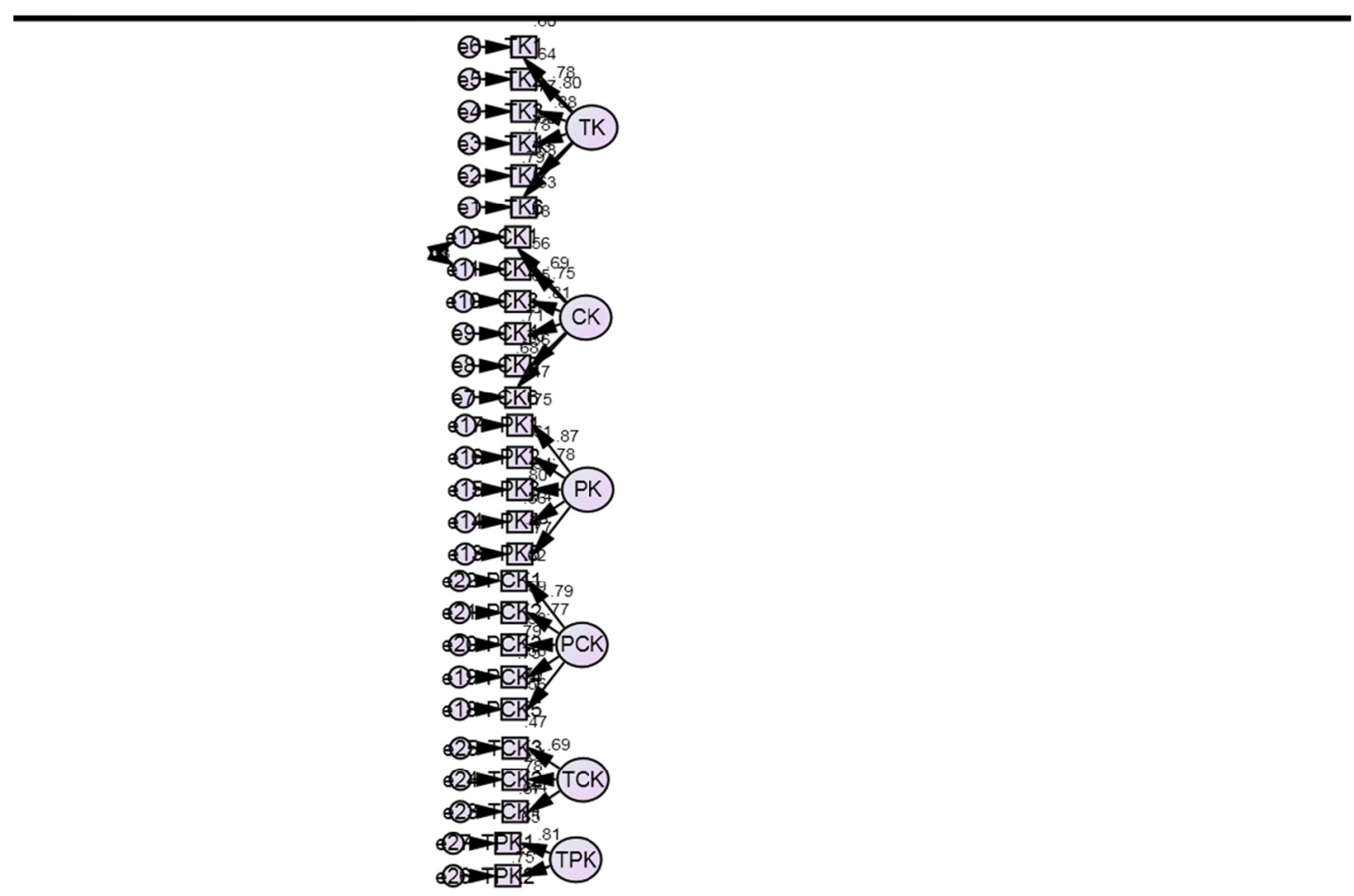

Figure 1. $1^{\text {st }}$ Order 6 Factors with No Correlation between Factors Model 


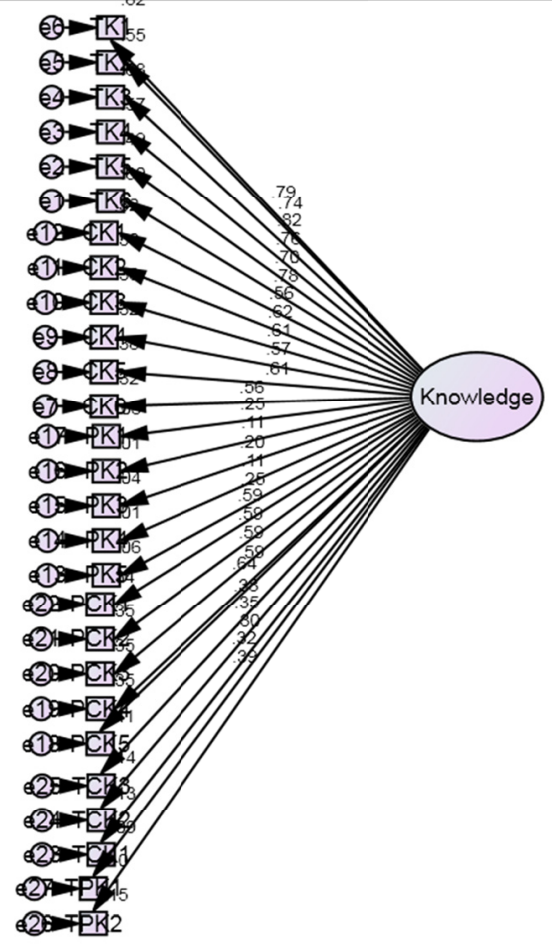

Figure 2. $1^{\text {st }}$ Order Single Factor Model

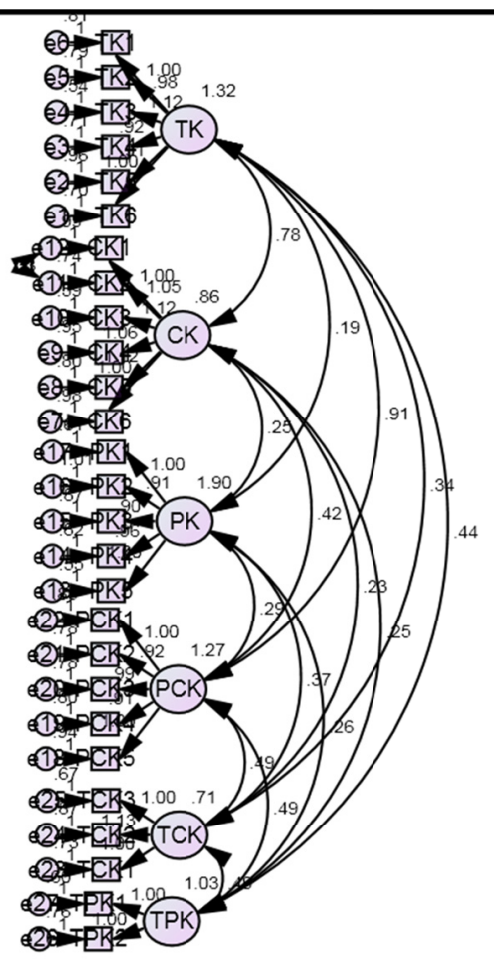

Figure 3. $1^{\text {st }}$ Order 6 Factors (with correlation) Model 


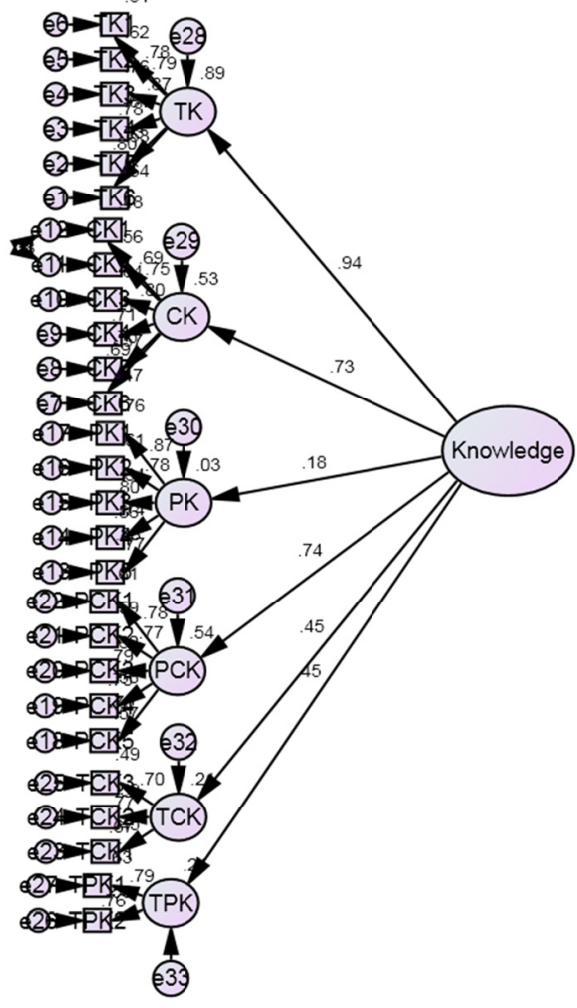

Figure 4. $2^{\text {nd }}$ Order 6 Factors Model

Table 4. Mode Fit Indices of Five Models

\begin{tabular}{|c|c|c|c|c|c|c|c|c|}
\hline & $X^{2}$ & df & $\mathrm{X}^{2} / \mathrm{df}$ & GFI & AGFI & NFI & CFI & RMSEA \\
\hline Null model & 2817.36 & 351 & 8.03 & .25 & .19 & 0 & 0 & .21 \\
\hline $\begin{array}{l}1^{\text {st }} \text { Order } \\
6 \text { factors } \\
\text { (no correlation) }\end{array}$ & 1469.64 & 323 & 4.55 & .52 & .43 & .48 & .54 & .15 \\
\hline $1^{\text {st }}$ order single factor & 689.49 & 329 & 2.10 & .76 & .72 & .76 & .85 & .08 \\
\hline $\begin{array}{l}1^{\text {st }} \text { Order } \\
6 \text { factors } \\
\text { (with correlation) }\end{array}$ & 435.20 & 314 & 1.39 & .84 & .81 & .85 & .95 & .05 \\
\hline $\begin{array}{l}2^{\text {nd }} \text { order } \\
6 \text { factors }\end{array}$ & 469.06 & 316 & 1.48 & .83 & .80 & .83 & .94 & .06 \\
\hline
\end{tabular}

As the Table 4 indicated, the fourth model $\left(1^{\text {st }}\right.$ Order 6 factors with correlation model $)$ reported a pretty sound model fit. All the indices of this model had made improvement. Furthermore, good-of-fit indices of $1^{\text {st }}$ Order 6 factors with correlation model as well as the $2^{\text {nd }}$ order 6 factors model were all acceptable; therefore, either one of these two models would be a good choice. Additionally, the Target Coefficient can be used to validate the necessity of the $2^{\text {nd }}$ order (in this present study which is TPACK) (Doll, Xia, \& Torkzadeh, 1994). The present study had the Target Coefficient of .92 which confirmed the necessity of TPACK because the Target Coefficient indicated the fact that $92 \%$ of the variance in fourth model can 
be explained by the fifth model.

According to the results of the $2^{\text {nd }}$ order 6 factors model, it can be reported that the standardised regression weight of PK was way too low for TPACK $(\beta=.18)$ while the $\beta$ value of TCK and TPK were a little bit lower than .50. On the other hand, the standardised regression weight of $\mathrm{TK}, \mathrm{CK}$ and $\mathrm{PCK}$ was all above .70 which indicated a strong predictability toward the construct of TPACK.

\section{Conclusion, Discussion and Future Work}

A successful implementation of computer-assisted instruction programme roots in teachers' knowledge on content-based technology integration (Harris \& Hofer, 2011) and computer-assisted language learning (CALL) is no exception. Teacher's competence on his/her TPACK has been acknowledged as an important issue (Bos, 2011) which calls for more exploration since TPACK is influenced greatly by contextual factors such as learning environment (Kelly, 2010), cultural as well as subject matters (Rosenberg, \& Koehler, 2015). EFL teachers around the world are gradually keen to exploit technology in their instruction; nevertheless, little is known about how they are ready for such use (Bos, 2011). As Mishra and Koehler (2006) has pointed out:

There is no single technological solution that applies for every teacher, every course, or every view of teaching. Quality teaching requires developing a nuanced understanding of the complex relationships [among] technology, content, and pedagogy, and using this understanding to develop appropriate, context-specific strategies and representations. ( $\mathrm{p}$. 1029)

Therefore, it is quite critical to understand EFL teachers' TPACK before the onset of any CALL programme. The purpose of this present was to examine the psychometric properties of measuring EFL teachers' Technological Pedagogical Content Knowledge (TPACK).

Using Exploratory Factor Analysis and Confirmatory Factory Analysis, the items developed by Baser et al. (2015) specifically for EFL teachers were examined. This study attempted to establish indicators which can properly reflect EFL teachers' TPACK whose L1 is Chinese. Results of EFA ruled out some items whose factor loading was below the threshold of .50 . Accordingly, this version of questionnaire was undergone a series of CFA modeling comparison to examine the interrelationship between knowledge because as Mishra and Koehler (2006) pointed out "...taking the knowledge structures apart would destroy the strength of the interconnectedness of the unified model and, thereby', misrepresent the TPACK model" (p. 1029). Results of CFA confirmed that $1^{\text {st }}$ Order 6 Factors (with correlation) Model had the best model fit indices but the $2^{\text {nd }}$ Order 6 Factors Model of this instrument had both theoretical and practical applicability in Taiwan as the Target Coefficient had confirmed.

Cognitive complexity is advised to be taken into consideration while examining teachers' TPACK because people with higher cognitive complexity are able to perform multidimensional tasks (Bos, 2011). While less complex people are able to be taught with a complex set of detailed distinctions for a specific context, people with more complexity will 
be more flexible while dealing with new situations (Streufert \& Swezey, 1986). Future studies may explore how individual's cognitive styles to provide more insights about EFL teachers' cognitive fidelity of integrating CALL in their instruction. Moreover, teachers may not be the only decision maker on the use of technology in instruction, Porras-Hernández and Salinas-Amescua (2013) suggested that we should look at the issue of teachers' TPACK from three perspectives, namely, Micro factors (in the classroom), Messo factors (in the school) and Macro (the societal condition) and such a hierarchical levels may significantly affect teachers' TPACK and thus warrant more empirical evidence.

Last but not least, the measures of content, pedagogical and technologicall knowledge should be separate or holistic is another interesting topic which needs further exploration. The inclusion of contextual factor should be undertaken in the future research of TPACK (Kelly, 2010).

\section{References}

Baser, D., Kopcha, T. J., \& Ozden, M. Y. (2015). Developing a technological pedagogical content knowledge (TPACK) assessment for preservice teachers learning to teach English as a foreign language. Computer Assisted Language Learning, 1-16. http://dx.doi.org/10.1080/09588221.2015.1047456

Bos, B. (2011). Professional development for elementary teachers using TPACK. Contemporary Issues in Technology and Teacher Education, 11(2), 167-183.

Bunch, J., Robinson, J. S., \& Edwards, M. C. (2015). Agriculture Teachers' Use of Interactive Whiteboards (IWBs): Teachers' Perceptions of Innovativeness and Technology Integration. Journal of Human Sciences and Extension Volume, 3(1), 63-79.

Debbagh, M., \& Jones, W. M. (2015). Using the TPACK Framework to Examine Technology Integration in English Language Teaching. Paper presented at the Society for Information Technology \& Teacher Education International Conference.

Deutsch, N. (2010). Instructor experiences with implementing technology in blended learning courses in higher education. Seattle, WA: Createspace.

Dina, A. T., \& Ciornei, S.-I. (2013). The Advantages and Disadvantages of Computer Assisted Language Learning and Teaching for Foreign Languages. Procedia - Social and Behavioral Sciences, 76, 248-252. http://dx.doi.org/10.1016/j.sbspro.2013.04.107

Doll, W. J., Xia, W., \& Torkzadeh, G. (1994). A confirmatory factor analysis of the end-user computing satisfaction instrument. Mis Quarterly, 453-461.

Egbert, J. (2005). CALL essentials: Principles and practice in CALL classrooms. Alexandria, VA: Teachers of English to Speakers of Other Languages (TESOL).

Flora, D. B., \& Curran, P. J. (2004). An empirical evaluation of alternative methods of estimation for confirmatory factor analysis with ordinal data. Psychological methods, 9(4), 466. 


\section{1ll Macrothink}

International Research in Education

ISSN 2327-5499

2016, Vol. 4, No. 1

Geourge, D., \& Mallery, P. (2003). SPSS for windows step by step: a simple guide and reference (4th ed.). Boston: Allyn and Bacon.

Hew, K. F., \& Cheung, W. S. (2014). Students' and instructors' use of massive open online courses (MOOCs): Motivations and challenges. Educational Research Review, 12, 45-58. http://dx.doi.org/10.1016/j.edurev.2014.05.001

Hsu, C.-K., Hwang, G.-J., \& Chang, C.-K. (2013). A personalized recommendation-based mobile learning approach to improving the reading performance of EFL students. Computers \& Education, 63, 327-336. http://dx.doi.org/10.1016/j.compedu.2012.12.004

Judith B. Harris \& Mark J. Hofer (2011) Technological Pedagogical Content Knowledge (TPACK) in Action. Journal of Research on Technology in Education, 43(3), 211-229. http://dx.doi.org/10.1080/15391523.2011.10782570

Kabakci Yurdakul, I., Odabasi, H. F., Kilicer, K., Coklar, A. N., Birinci, G., \& Kurt, A. A. (2012). The development, validity and reliability of TPACK-deep: A technological pedagogical content knowledge scale. Computers \& Education, 58(3), 964-977. http://dx.doi.org/10.1016/j.compedu.2011.10.012

Kelly, M. (2010). Technological pedagogical content knowledge (TPACK): A content analysis of 2006-2009 print journal articles. Paper presented at the Society for Information Technology \& Teacher Education International Conference.

Koçoğlu, Z. (2009). Exploring the technological pedagogical content knowledge of pre-service teachers in language education. Procedia-Social and Behavioral Sciences, 1(1), 2734-2737.

Kurt, G., Mishra, P., \& Kocoglu, Z. (2013). Technological pedagogical content knowledge development of Turkish pre-service teachers of English. Paper presented at the Society for Information Technology \& Teacher Education International Conference.

Levy, M. (1997). CALL: context and conceptualisation. Oxford: Oxford University Press.

Martin, K. J. (2015). Implementing Online Learning for the ESL Classroom: Tips and Strategies for Starting or Improving the Online Second Language Classroom. Paper presented at the Society for Information Technology \& Teacher Education International Conference.

Mishra, P., \& Koehler, M. (2006). Technological pedagogical content knowledge: A framework for teacher knowledge. The Teachers College Record, 108(6), 1017-1054.

Nachoua, H. (2012). Computer-Assisted Language Learning for Improving Students' Listening Skill. Procedia - Social and Behavioral Sciences, 69, 1150-1159. http://dx.doi.org/10.1016/j.sbspro.2012.12.045

Oblinger, D. (2003). Boomers gen-xers millennials. EDUCAUSE Review, 500(4), 37-47.

Oblinger, D. G. (2010). The next generation of educational engagement. Journal of interactive media in education, 2004(1), Art. 10. 


\section{MInstitute Macrothink $_{\text {Int }}$}

International Research in Education ISSN 2327-5499 2016, Vol. 4, No. 1

Porras-Hernández, L. H., \& Salinas-Amescua, B. (2013). Strengthening TPACK: A broader notion of context and the use of teacher's narratives to reveal knowledge construction. Journal of Educational Computing Research, 48(2), 223-244.

Prensky, M. (2001). Digital natives, digital immigrants part 1. On the horizon, 9(5), 1-6.

Levy, M. (1997). CALL: context and conceptualisation. Oxford: Oxford University Press.

Martin, K. J. (2015). Implementing Online Learning for the ESL Classroom: Tips and Strategies for Starting or Improving the Online Second Language Classroom. Paper presented at the Society for Information Technology \& Teacher Education International Conference.

Mishra, P., \& Koehler, M. (2006). Technological pedagogical content knowledge: A framework for teacher knowledge. The Teachers College Record, 108(6), 1017-1054.

Nachoua, H. (2012). Computer-Assisted Language Learning for Improving Students' Listening Skill. Procedia - Social and Behavioral Sciences, 69, 1150-1159. http://dx.doi.org/10.1016/j.sbspro.2012.12.045

Oblinger, D. (2003). Boomers gen-xers millennials. EDUCAUSE Review, 500(4), 37-47.

Oblinger, D. G. (2010). The next generation of educational engagement. Journal of interactive media in education, 2004(1), Art. 10.

Porras-Hernández, L. H., \& Salinas-Amescua, B. (2013). Strengthening TPACK: A broader notion of context and the use of teacher's narratives to reveal knowledge construction. Journal of Educational Computing Research, 48(2), 223-244.

Prensky, M. (2001). Digital natives, digital immigrants part 1. On the horizon, 9(5), 1-6.

Rosenberg, J. M., \& Koehler, M. J. (2015). Context and Technological Pedagogical Content Knowledge (TPACK): A Systematic Review. Journal of Research on Technology in Education, 47(3), 186-210.

Roth, R. (2015). Frameworks for Integration of Digital Technologies at the Roadside: Innovative Models, Current Trends and Future Perspectives. International Journal of Learning, Teaching and Educational Research, 13(2), 37-54.

Streufert, S., \& Swezey, R. W. (1986). Complexity, managers, and organizations. New York, NY: Academic Press.

Schmid, R.F., Bernard, R.M., Borokhovski, E., Tamim, R.M., Abrami, P.C., Surkes, M.A., Wade, C.A. and Woods, J. (2014). The effects of technology use in postsecondary education: A meta-analysis of classroom applications. Computers \& Education, 72, 271-291. http://dx.doi.org/10.1016/j.compedu.2013.11.002

Shulman, L. S. (1986). Those who understand: knowledge growth in teaching. Educational Researcher, 15(2), 4-14.

Tamim, R. M., Bernard, R. M., Borokhovski, E., Abrami, P. C., \& Schmid, R. F. (2011). What 
forty years of research says about the impact of technology on learning a second-order meta-analysis and validation study. Review of Educational research, 81(1), 4-28.

Tamim, R. M., Borokhovski, E., Pickup, D., Bernard, R. M., \& El Saadi, L. (2015). Tablets for Teaching and Learning: A Systematic Review and Meta-Analysis.

Thompson, A., \& Mishra, P. (2007). Breaking news: TPCK becomes TPACK! Journal of Computing in Teacher Education, 24(2), 38.

Wu, Q. (2015). Designing a smartphone app to teach English (L2) vocabulary. Computers \& Education, 85, 170-179. http://dx.doi.org/10.1016/j.compedu.2015.02.013

Wurst, C., Smarkola, C., \& Gaffney, M. A. (2008). Ubiquitous laptop usage in higher education: Effects on student achievement, student satisfaction, and constructivist measures in honors and traditional classrooms. Computers \& Education, 51(4), 1766-1783. http://dx.doi.org/10.1016/j.compedu.2008.05.006

\section{Appendix}

TPACK-EFL Questionnaire

\begin{tabular}{|c|c|c|}
\hline Construct & & Item \\
\hline \multirow[t]{6}{*}{$\begin{array}{l}\text { Technological Knowledge } \\
\text { (TK) }\end{array}$} & TK1 & $\begin{array}{l}\text { I can use basic technological terms (e.g. operating system, } \\
\text { wireless connection, virtual memory, etc.) appropriately. }\end{array}$ \\
\hline & TK2 & $\begin{array}{l}\text { I can adjust computer settings such as installing software and } \\
\text { establishing an Internet connection. }\end{array}$ \\
\hline & TK3 & $\begin{array}{l}\text { I can troubleshoot common computer problems (e.g. printer } \\
\text { problems, Internet connection problems, etc.) independently. }\end{array}$ \\
\hline & TK4 & $\begin{array}{l}\text { I can create multimedia (e.g. video, web pages, etc.) using } \\
\text { text, pictures, sound, video, and animation. }\end{array}$ \\
\hline & TK5 & $\begin{array}{l}\text { I can use collaboration tools (wiki, edmodo, 3D virtual } \\
\text { environments, etc.) in accordance with my objectives. }\end{array}$ \\
\hline & TK6 & $\begin{array}{l}\text { I can learn software that helps me complete a variety of tasks } \\
\text { more efficiently. }\end{array}$ \\
\hline \multirow{6}{*}{$\begin{array}{l}\text { Content Knowledge } \\
\text { (CK) }\end{array}$} & CK1 & I can express my ideas and feelings by writing in English. \\
\hline & $\mathrm{CK} 2$ & $\begin{array}{l}\text { I can read texts written in English with the correct } \\
\text { pronunciation. }\end{array}$ \\
\hline & CK3 & I can understand texts written in English. \\
\hline & CK4 & I can understand the speech of a native English speaker easily. \\
\hline & CK5 & I am familiar with the grammar of English. \\
\hline & CK6 & I have no problem communicating with people in English. \\
\hline \multirow[t]{3}{*}{$\begin{array}{l}\text { Pedagogical Knowledge } \\
(\mathrm{PK})\end{array}$} & PK1 & $\begin{array}{l}\text { I can use teaching methods and techniques that are } \\
\text { appropriate for a learning environment. }\end{array}$ \\
\hline & PK2 & $\begin{array}{l}\text { I can design a learning experience that is appropriate for the } \\
\text { level of students. }\end{array}$ \\
\hline & PK3 & I can support students' learning in accordance with their \\
\hline
\end{tabular}


PK4 I can collaborate with school stakeholders (students, parents, teachers, etc.) to support students' learning.

PK5 I can support students' out-of-class work to facilitate their self-regulated learning.

\begin{tabular}{|c|c|c|}
\hline \multirow{5}{*}{$\begin{array}{l}\text { Pedagogical content } \\
\text { knowledge (PCK) }\end{array}$} & PCK1 & I can manage a classroom learning envïronment. \\
\hline & PCK2 & I can evaluate students' learning procesises. \\
\hline & PCK3 & $\begin{array}{l}\text { I can use appropriate teaching methods and techniques to } \\
\text { support students in developing their language skills. }\end{array}$ \\
\hline & PCK4 & $\begin{array}{l}\text { I can prepare curricular activities that develop students' } \\
\text { language skills. }\end{array}$ \\
\hline & PCK5 & $\begin{array}{l}\text { I can adapt a lesson plan in accordance with students' } \\
\text { language skill levels. }\end{array}$ \\
\hline \multirow[t]{3}{*}{$\begin{array}{l}\text { Technological content } \\
\text { knowledge (TCK) }\end{array}$} & TCK1 & $\begin{array}{l}\text { I can take advantage of multimedia (e.g. video, slideshow, } \\
\text { etc.) to express my ideas about various topics in English. }\end{array}$ \\
\hline & TCK2 & $\begin{array}{l}\text { I can benefit from using technology (e.g. web conferencing } \\
\text { and discussion forums) to contribute at a distance to } \\
\text { multilingual communities. }\end{array}$ \\
\hline & TCK3 & $\begin{array}{l}\text { I can use collaboration tools to work collaboratively with } \\
\text { foreign persons (e.g. Second Life, wiki, etc.). }\end{array}$ \\
\hline \multirow[t]{2}{*}{$\begin{array}{l}\text { Technological pedagogical } \\
\text { knowledge (TPK) }\end{array}$} & TPK1 & $\begin{array}{l}\text { I can support students as they use technology such as virtual } \\
\text { discussion platforms to develop their higher order thinking } \\
\text { abilities. }\end{array}$ \\
\hline & TPK2 & $\begin{array}{l}\text { I can design learning materials by using technology that } \\
\text { supports students' language learning. }\end{array}$ \\
\hline $\begin{array}{l}\text { Technological Pedagogical Content } \\
\text { Knowledge }\end{array}$ & TPACK1 & $\begin{array}{l}\text { I can support my professional development by using } \\
\text { technological tools and resources to continuously improve the } \\
\text { language teaching process. }\end{array}$ \\
\hline
\end{tabular}

\section{Copyright Disclaimer}

Copyright reserved by the authors.

This article is an open-access article distributed under the terms and conditions of the Creative Commons Attribution license (http://creativecommons.org/licenses/by/3.0/). 